Wright State University

CORE Scholar

\title{
Courts as Casinos? An Empirical Investigation of Randomness and Efficiency in Civil Litigation
}

\author{
Evan W. Osborne \\ Wright State University - Main Campus, evan.osborne@wright.edu
}

Follow this and additional works at: https://corescholar.libraries.wright.edu/econ

Part of the Economics Commons

\section{Repository Citation}

Osborne, E. W. (1999). Courts as Casinos? An Empirical Investigation of Randomness and Efficiency in Civil Litigation. Journal of Legal Studies, 28 (1), 187-203.

https://corescholar.libraries.wright.edu/econ/1

This Article is brought to you for free and open access by the Economics at CORE Scholar. It has been accepted for inclusion in Economics Faculty Publications by an authorized administrator of CORE Scholar. For more information, please contact library-corescholar@wright.edu. 


\title{
COURTS AS CASINOS? AN EMPIRICAL INVESTIGATION OF RANDOMNESS AND EFFICIENCY IN CIVIL LITIGATION
}

\author{
EVAN OSBORNE*
}

\begin{abstract}
For a variety of reasons, the U.S. legal system has been accused of performing poorly because of the haphazard way in which courts assess liability and award damages. This article examines the relation of court awards to the pretrial expectations of litigants and their attorneys and to measurable, economically relevant damages. Court awards are highly predictable, as variance in expectations explains much of the variance in awards. In addition, awards are significantly related to both medical costs and property damage. The hypothesis of a highly unpredictable court system is conclusively rejected.
\end{abstract}

\section{INTRODUCTION}

$\mathrm{O}$ NE of the most common charges levied against the American civil litigation regime is that it is far too random. Critics of the system maintain that court verdicts and awards are unpredictable and often unrelated to any reasonable notion of fault, so that its alleged benefits, whether in terms of economic efficiency or the rendering of justice, are overstated. The criticism is made not just by businesses ${ }^{1}$ and insurers, ${ }^{2}$ who might be expected to harbor such sentiments, but by economists ${ }^{3}$ and legal scholars. ${ }^{4}$ Indeed, one economist goes so far as to argue that certain empirical parameters of the civil litigation system so closely resemble similar figures for state lot-

* Assistant professor of economics, Wright State University. I thank, without implicating, both an anonymous referee and William M. Landes for very helpful assistance.

${ }^{1}$ E. Patrick McGuire, The Impact of Product Liability (1988).

${ }^{2}$ Clark Embler, Pollution and Liability, 8 Corp. Board 13 (1987).

${ }^{3}$ Dick Netzer, On "Auto Choice," Only the Lawyers Lose, letter, N.Y. Times, January 31, 1997; Robert E. Litan, Peter Swire, \& Clifford Winston, The U.S. Liability System: Background and Trends, in The Liability Maze: The Impact of Liability on Safety and Innovation (Peter W. Huber \& Robert E. Litan eds. 1991).

${ }^{4}$ Christopher P. Bowers, Courts, Contracts and the Appropriate Discount Rate: A Quick Fix for the Legal Lottery, 63 U. Chi. L. Rev. 1099 (1996).

[Journal of Legal Studies, vol. XXVIII (January 1999)]

(C) 1999 by The University of Chicago. All rights reserved. 0047-2530/99/2801-0002\$01.50 
tery systems that the former is best understood as a purposefully constructed version of the latter. ${ }^{5}$

Despite widespread complaints about the liability lottery, there have been no comprehensive attempts to measure the extent to which civil-court verdicts can be predicted. This article seeks to assess unpredictability and inefficiency in U.S. civil litigation by answering two questions. First, are verdicts and judgments predictable, so that rational litigants may anticipate court behavior and react accordingly? And second, if so, to what extent are differences in court awards related to differences in economically relevant details of the case? The study will build on two previous strands of literature. The first is a series of studies, most involving medical malpractice, on the relation between defendant conduct and lawsuit outcomes. Work by Henry Farber and Michelle White, Patricia Danzon, and Frank Sloan and Chee Ruey Hsieh shows that the chances of having a case dropped, the chances of the plaintiff winning, and the amount he or she wins are correlated in the economically expected way with measures of defendant misconduct. ${ }^{6}$ However, a weakness of these studies is that they use only a few discrete measures of defendant conduct and plaintiff harm. In the most thorough measure, Sloan and Hsieh employed variables for injury severity and degree of defendant misconduct that took whole-number values from one to eight. Elisabeth Landes found a significant relation between the continuous variables of measurable economic loss and tort compensation, but her sample was confined to automobile-accident litigation, and her methods left open the possibility that "tort compensation has some aspects of a lottery." 7 This article will also use continuous measures of actual and expected damages but will do so for a wide variety of categories of law. It will also for the first time make use of continuous measures of the expected value of the lawsuit to litigants.

In addition, Theodore Eisenberg et al. recently assessed patterns in punitive damages and found that such damages are predictable and economically sensible. ${ }^{8}$ However, their test of sensibility was a comparison of puni-

${ }^{5}$ William T. Harris, A Public Choice Analysis of the Evolution of Tort Law: Liabilities, Lotteries and Redistribution, 51 Am. J. Econ. \& Soc. 101 (1992).

${ }^{6}$ Henry S. Farber \& Michelle J. White, Medical Malpractice: An Empirical Investigation of the Litigation Process, 22 Rand J. Econ. 199 (1991); Patricia Munch Danzon, Medical Malpractice: Theory, Evidence and Public Policy (1985); Frank A. Sloan \& Chee Ruey Hsieh, Variability in Medical Malpractice Payments: Is the Compensation Fair? 24 Law \& Soc. Rev. 997 (1990).

${ }^{7}$ Elisabeth M. Landes, Compensation for Automobile Accident Injuries: Is the Tort System Fair? 11 J. Legal Stud. 253, 256 (1981).

${ }^{8}$ Theodore Eisenberg et al., The Predictability of Punitive Damages, 26 J. Legal Stud. 623 (1997). 
tive to compensatory damages. Critically, they assumed that compensatory damages are closely related to actual, economically relevant harm. ${ }^{9}$ There is as yet no empirical support for this proposition, and although punitive damages draw the headlines, compensatory damages are far more important in the day-to-day functioning of the courts. This article thus investigates whether all damages, punitive and compensatory, are related to harm and to expectations about trial. Section II sets up the problem to be explained and examines how predictable awards are, and Section III examines the relation between awards and economic fundamentals.

\section{The Predictability of Awards}

I will assume that the lawsuit is an exercise in rational choice under uncertainty, in the sense that effort is chosen so that the expected value of the lawsuit is maximized, given that at least the outcome and perhaps even the size of the award is uncertain. ${ }^{10} \mathrm{We}$ might imagine that $A$, the award in the event the suit proceeds all the way to final disposition, can be estimated through its expected value $E(A)=f(X)$, and that the award itself is given by $A=f(X)+u$. The variable $X$ is a set of exogenous variables, and $u$ is a random shock distributed according to some known density function $g\left(u \mid 0, \sigma^{2}\right)$. The variable $X$ will include a large number of factors, including but not limited to the facts of the case, the relevant law, the skill of each attorney, and the history of the particular court with respect to procedural issues or sympathy for plaintiffs or defendants.

The more that the variance in awards is related to variance in $X$, the greater is the predictability of the court system. Economic analysis of litigation indicates that some unpredictability must exist, as trials result from litigants' estimates of trial outcomes that are erroneous on at least one side. Often these models produce equilibria in which a fraction of cases go to trial depending on information that is unknown to both litigants at the time they must decide whether to settle or go to trial, including different estimates of the stakes or of defendant fault by each litigant. ${ }^{11}$ Note that the performance by the court system of the tasks assigned to it in the economic model of litigation does not simply require that awards be substantially pre-

${ }^{9}$ Eisenberg et al. state: "In tort cases eligible for punitive damages, a convenient measure of the degree of harm caused by the defendant usually exists. The compensatory component of the damages award should be a measure of the harm the defendant has caused." Id. at 628.

${ }^{10}$ A paper that is often credited as the first examination of litigation as a rational, optimizing investment is William M. Landes, An Economic Analysis of the Courts, 14 J. Law \& Econ. 61 (1971).

${ }^{11}$ Many papers are based on this belief. See, for example, George Priest \& Benjamin Klein, The Selection of Disputes for Litigation, 13 J. Legal Stud. 1 (1984). 
dictable. Awards should also be related to factors that contribute to social welfare maximization, such as the efficient allocation of risk and, most important in the analysis below, the bearing of the relevant burdens by the party that could have done so at least cost ex ante.

The null hypothesis is that awards by courts are so unpredictable as to add great risk to market exchange. Greater unpredictability in court awards means that insurance against the vagaries of the liability system is harder to obtain, and producers may respond by avoiding any productive activity that is sufficiently hampered by litigation risk. If awards are predictable, then employers should be able to anticipate the sorts of circumstances that will give rise to litigation and court-imposed penalties and to take action to avoid those circumstances where it is efficient to do so. The high percentage of cases that settle out of court provides some evidence, admittedly tentative, that court awards are not as random as is sometimes claimed. ${ }^{12}$

The randomness hypothesis can be tested more concretely by measuring the relation between court awards and ex ante expectations of those awards. Such data are found in the Civil Litigation Research Project (CLRP). This data set contains information that is a very close proxy for what representing attorneys thought the gross expected values of their cases were. Attorneys were asked, after the fact, the maximum amount their clients should have accepted to settle the case. Of course, ex ante estimations would be ideal, but there are two reasons to suppose that the stakes variable contained in the report is an adequate approximation of $f(X)$. The first is that the researchers carefully designed an oral interview questionnaire to obtain precisely that answer from attorneys who were able to consult written records. ${ }^{13}$ Second, and more important, empirical work demonstrates that these estimations were in fact an important predictor of eventual attorney effort in the case, indicating that the ex post estimations were closely related to ex ante optimizing behavior. ${ }^{14}$ The advantage of having this measure is that with rational litigants it should capture all relevant information that can be

12 The evidence is tentative because even modest unpredictability could generate a high rate of settlement if litigants are sufficiently risk averse.

${ }^{13}$ The interviewer first asked the attorney, "At that time, what did you think should have been done to settle the problem?"' If no money figure was mentioned, the follow-up question was, "Suppose that there could have been a settlement at that time which involved only a lump sum payment of money. What would you think it should have been?"' This information comes from the data set codebook, Herbert M. Kritzer et al., Civil Litigation Research Project Data Archive Revision, 1988-81, at 21 (1987). The survey was not sufficiently detailed to indicate which records were consulted in the creation of specific variables. However, it does indicate that of 256 observations in the broadest sample used in the analysis (see Section IIA infra), information on whether records were consulted in the interview was available in 212. They were used in 169.

${ }^{14}$ David Trubek et al., The Costs of Ordinary Litigation, 31 UCLA L. Rev. 72 (1983). 
TABLE 1

Description of Civil Litigation Research Project Data

A. Breakdown of Data Subsets

\begin{tabular}{lrcrcc}
\hline \hline Data Subset & $N$ & $\begin{array}{c}\text { Number } \\
\text { of Cases }\end{array}$ & $\begin{array}{c}\text { State } \\
\text { Court }\end{array}$ & $\begin{array}{c}\text { Federal } \\
\text { Court }\end{array}$ & $\begin{array}{c}\text { Unknown/ } \\
\text { Other }\end{array}$ \\
\hline Full data set & N.A. & 2,582 & 809 & 840 & 933 \\
Full sample & 256 & 196 & 80 & 89 & 27 \\
No outright defendant & & & & & 27 \\
$\quad$ victories & 216 & 166 & 72 & 67 & N.A. \\
Judges & 80 & 66 & 26 & 40 & N.A. \\
Juries & 30 & 18 & 6 & 12 & \\
\hline \hline
\end{tabular}

B. Summary Statistics (in Dollars)

\begin{tabular}{lrrrrr}
\hline Data Subset & Mean & Median & SD & Minimum & Maximum \\
\hline Full data set: & & & & & \\
$\quad$ AWARD & 25,110 & 4,370 & 180,366 & 0 & $5,225,000$ \\
$\quad$ STAKES & 37,481 & 8,016 & 131,819 & 0 & $2,500,000$ \\
Full sample: & & & & & \\
$\quad$ AWARD & 14,312 & 2,633 & 32,386 & 0 & 235,000 \\
$\quad$ STAKES & 32,959 & 7,500 & 103,144 & 0 & $1,100,000$ \\
No outright defendant & & & & & \\
$\quad$ victories: & & & & & \\
$\quad \begin{array}{l}\text { AWARD } \\
\text { STAKES }\end{array}$ & 16,963 & 4,000 & 34,624 & 0 & 235,000 \\
Judges: & 34,251 & 6,935 & 108,591 & 0 & $1,100,000$ \\
$\quad \begin{array}{l}\text { AWARD } \\
\text { STAKES }\end{array}$ & 15,412 & 1,108 & 32,905 & 0 & 200,000 \\
Juries: & 34,636 & 10,000 & 90,412 & 300 & 675,000 \\
$\quad$ AWARD & & & & & \\
$\quad$ STAKES & 11,080 & 3,794 & 17,584 & 0 & 87,500 \\
\hline
\end{tabular}

NotE. - N.A. $=$ not applicable.

obtained at a nonprohibitive cost. The use of expectations as the exogenous variable thus has the useful feature of incorporating all the factors that such litigants need to make their optimizing decision in pursuing litigation.

\section{A. The Data}

The CLRP data were generated from surveys of litigants and attorneys in almost 2,000 cases drawn from federal and state courts and arbitration bodies in five federal judicial districts, and included many areas of law. All cases in the data set were terminated between 1977 and 1979. Although government and private cases were included in the full sample, because there were so few observations involving government litigants that contained stakes information, I examine only private litigants. Table 1 contains 
summaries about awards and beliefs about the amount at stake (STAKES) in the full data set and all subsets of it used in this article. "Full data set" refers to the entire CLRP data set, "Full sample" to the most comprehensive sample used in the analysis below (that is, all observations containing the necessary information), and "No outright defendant victories" to the full sample without those cases in which the plaintiff received nothing. Recall that in the standard economic model of litigation the existence of trials and of findings of no liability implies some unpredictability, and a full measure of the predictability of the judicial process requires that erroneous expectations of a liability finding be included as well. However, the "No outright defendant victories" set is included because analysis of those cases in isolation will be of interest in Subsection C below. "Judges" and "Juries" refer to observations in which the final decision was known to be rendered by those methods. Note that there is significant data attrition in proceeding to the last two sets. This is due to both the inclusion of arbitration awards in the broadest set and missing information on the manner of adjudication. $^{15}$

The top portion of Table 1 contains summary information on the entire data set and the various subsets used here. Note first that there is a distinction between the number of observations and the number of cases. This is because in some cases information was available for both plaintiffs and defendants, and in some cases there were multiple plaintiffs or defendants. Each litigant is coded as a separate observation, and the top portion of the table helps determine the number of cases that made up the larger number of observations. In addition, the CLRP data were drawn from state and federal courts in five federal judicial districts, and the breakdown of cases between state court, federal court, and alternative-dispute resolution or unknown venue is included. ${ }^{16}$

The cases of interest are those that proceeded to a final decision rather than those that were dropped or settled, and so the numbers in Table 1 (with the exception of the row containing information on the entire data set) refer to only the former. The lower portion of the table contains information on means, standard deviations, and maxima and minima for each set, for both the monetary award of the court, AWARD, and STAKES. These figures are included to indicate that the judge and jury subsets are not consequentially

15 Data on the manner of adjudication were missing in 111 observations.

${ }^{16}$ The five federal districts from which observations were drawn were two larger urban districts (Philadelphia, Los Angeles), two smaller urban districts (Milwaukee and Columbia, S.C.), and one predominantly rural district (New Mexico, with the court located in Albuquerque). In addition, approximately 30 state-court cases in the Philadelphia and Milwaukee districts were taken from the Chester County Court of Common Pleas and the Dodge County Circuit Court, respectively. Kritzer et al., supra note 13. 
different from the broader data sets and, indeed, that the stakes and awards in all the cases that were not settled are not radically different from all cases that were originally filed.

Finally, the CLRP data are not, strictly speaking, a random sample of lawsuits. Lawsuits with stakes under $\$ 1,000$ were deleted by the data set's creators unless there were substantial nonmonetary issues (for example, discrimination) at stake. Very large cases were also deleted, but rather than delete such cases according to the size of awards as such, Kritzer et al. deleted cases with exceptionally large court records. This led to the exclusion of 32 cases from federal court and four from the state court in California, out of 2,582 cases eventually included in the full set. As Table 1 indicates, the range of both awards and perceived stakes is still quite large in the cases that remain. In fact, in each case the median is significantly less than the mean for both $A W A R D$ and STAKES, due to the presence of a few very large cases.

Other exclusion criteria potentially affecting the data set's representativeness include the need to obtain permission of some survey participants and a ceiling placed on divorce cases in some jurisdictions, which would otherwise have constituted what Kritzer et al. believed to be an excessive proportion of the data set. Finally, cases in which conflict in civil matters was not a central part of the dispute, such as uncontested probate cases or deportation proceedings, were not included. Some of these problems are commonplace in survey collection, while others represent choices made by the creators. The data set has nonetheless been widely used in empirical work. Its full exclusion criteria can be found in the data set's codebook. ${ }^{17}$

\section{B. Results for the Comprehensive Set}

Figures 1 and 2 depict two scatterplots of AWARD and STAKES. Figure 1 contains all observations with nonzero awards in which each variable is less than $\$ 80,000$. The cutoff point is chosen so as to obtain a large number of observations $(N=198)$ while not incorporating a range of cases so large as to render the diagram uninformative. Figure 2 contains a more focused examination of those cases in which each variable was less than $\$ 5,000(N$ $=84$ ). The rough comovement between the two variables is evident in each case. The Pearson correlation measure between AWARD and STAKES for all observations containing both variables is $\rho=0.54$.

Regression analysis allows for a more rigorous assessment. The results for the broadest sample are presented in the first column of Table 2. It contains an ordinary least-squares regression of $A W A R D$ on STAKES and on a 


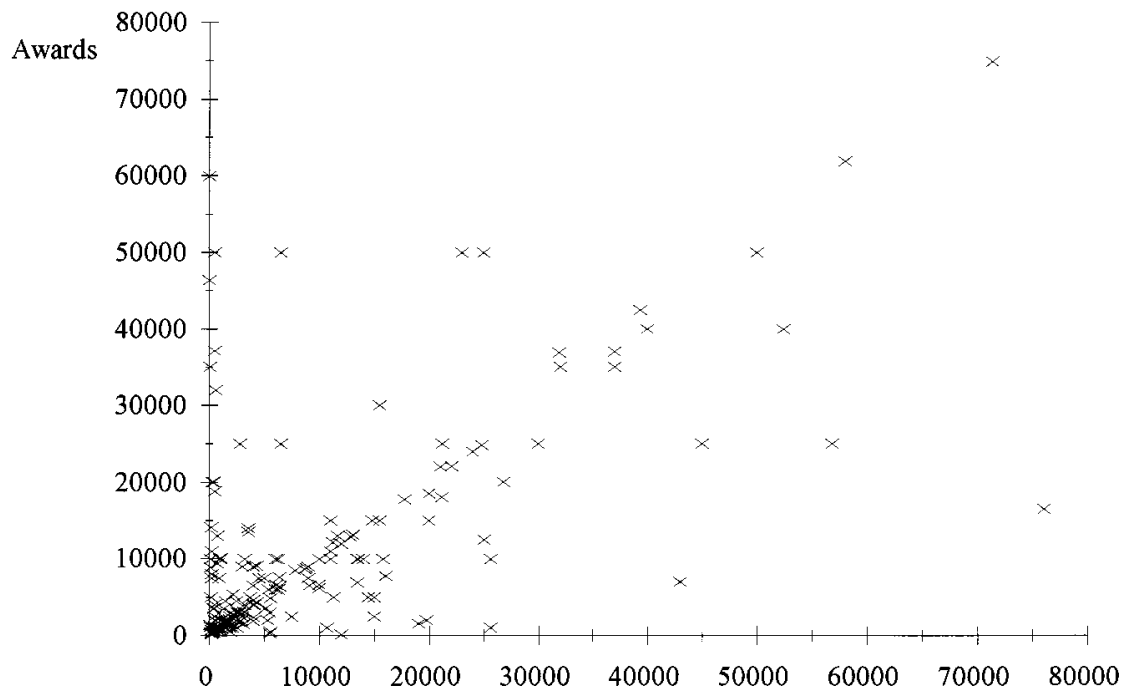

FIGURE 1.-Observations with nonzero awards in which each variable is less than $\$ 80,000$



FigurE 2.-Examination of those cases in which each variable is less than $\$ 5,000$ 
TABLE 2

Relation between Court Awards and Expectations

\begin{tabular}{|c|c|c|}
\hline Variable & $\begin{array}{l}\text { Full Sample } \\
\text { Coefficient }\end{array}$ & $\begin{array}{l}\text { Without Defendant } \\
\text { Victories Coefficient }\end{array}$ \\
\hline STAKES & $\begin{array}{l}.166082 * * * \\
(9.956)\end{array}$ & $\begin{array}{l}.174767 * * * \\
(9.666)\end{array}$ \\
\hline TORTS & $\begin{array}{c}-5,387.236519 \\
(-1.228)\end{array}$ & $\begin{array}{c}-6,438.919332 \\
(-1.269)\end{array}$ \\
\hline CONTRACT & $\begin{array}{c}3,818.419346 \\
(.925)\end{array}$ & $\begin{array}{c}4,688.076808 \\
(.999)\end{array}$ \\
\hline FAMILY & $\begin{array}{r}-13,110 \\
(-1.541)\end{array}$ & $\begin{array}{l}-16,072 * \\
(-1.794)\end{array}$ \\
\hline PROPERTY & $\begin{array}{c}8,671.336530 \\
(1.063)\end{array}$ & $\begin{array}{c}6,410.894721 \\
(.711)\end{array}$ \\
\hline$\angle A B O R$ & $\begin{array}{c}-9,610.690156 \\
(-1.465)\end{array}$ & $\begin{array}{r}-11,496 \\
(-1.409)\end{array}$ \\
\hline PRODUCTS & $\begin{array}{c}4,731.010663 \\
(.296)\end{array}$ & $\begin{array}{c}-110.009316 \\
(-.007)\end{array}$ \\
\hline$M A L P R A C$ & $\begin{array}{c}-9,006.644564 \\
(-.565)\end{array}$ & $\begin{array}{l}-11,879 \\
\quad(-.710)\end{array}$ \\
\hline INTPROP & $\begin{array}{c}9,945.367336 \\
(.624)\end{array}$ & $\begin{array}{c}6,219.597573 \\
(.372)\end{array}$ \\
\hline FIRM & $\begin{array}{r}10,569 * * * \\
(3.439)\end{array}$ & $\begin{array}{r}12,542 * * * \\
(3.645)\end{array}$ \\
\hline$A R B$ & $\begin{array}{c}-7,809.524516 \\
(-1.581)\end{array}$ & $\begin{array}{l}-10,907 * \\
(-1.997)\end{array}$ \\
\hline PLAINTIFF & $\begin{array}{c}2,584.470625 \\
(.819)\end{array}$ & $\begin{array}{c}5,135.957196 \\
(1.404)\end{array}$ \\
\hline$\underline{\rho}$ & .46360 & .56778 \\
\hline $\bar{R}^{2}$ & .4132 & .4589 \\
\hline$F$ & 16.024 & 16.266 \\
\hline$p$ & .0001 & .0001 \\
\hline$N$ & 256 & 216 \\
\hline
\end{tabular}

series of dummy variables. The variables TORTS, CONTRACT, FAMILY, PROPERTY, LABOR, PRODUCTS, MALPRAC, and INTPROP take the value one if the observation was, respectively, a torts, contracts, family-law, property, labor-law (including discrimination), products-liability, malpractice, or intellectual property case. In this and all subsequent regressions, these categories make up the bulk of the sample. The variable FIRM is zero if the attorney is a sole practitioner and one otherwise. FIRM is included to test whether sole proprietor-entrepreneurs behave differently from larger law firms. Among the reasons an attorney in the former environment might act differently in estimating what his client should settle for are different 
agency problems in the two types of legal firms, both among attorneys in larger firms and between client and attorney in both firm types, or different abilities to spread risk. The variable $A R B$ is a dummy variable taking the value one if the case was heard by an arbitration panel and zero if the verdict was rendered by a court. The variable PLAINTIFF is a dummy taking the value one for all observations in which the STAKES estimate was made by a plaintiff attorney and zero if the estimate was made by a defendant attorney.

The model does an excellent job in explaining the variance in awards, as the adjusted $R^{2}$ figure $\left(\bar{R}^{2}\right)$ is 0.41 . In addition, stakes are highly significant $(p<.0001)$. The proportion of variance in awards explained by variance in expectations is strongly indicative of the predictability of the court system. If "randomness" in the awarding of damages is taken to mean that litigants' ex ante expectations of what courts will do does not explain much of what courts actually do, this hypothesis can be conclusively rejected.

It is interesting that none of the case-type dummy variables are statistically significant. A model of stakes estimation as a rational activity implies that obviously accessible information such as case type would be incorporated in stakes estimation, and the evidence is consistent with this hypothesis. If certain types of cases lead to different patterns of court awards, as is sometimes claimed, attorneys are evidently aware of these tendencies. Indeed, the deterioration in goodness-of-fit measures when all dummies are excluded is negligible. ${ }^{18}$ Even without accounting for differences in the way the court system adjudicates different case types that are unobservable to attorneys, the explained variance is almost equal. However, working in a multilawyer firm has a statistically significant upward effect on the award.

\section{Excluding Outright Defendant Victories}

It is possible that the results indicate an ability to broadly predict wins and losses rather than to make a good estimate of the award itself. In order to test this possibility, I include in the second column of Table 2 the same regression run on the full sample, less observations in which the plaintiff received nothing. There were 40 such outright defendant victories in the full set. When they are excluded, the results are not significantly different. The correlation coefficient is $\rho=0.57$, and the explained variance in the full regression is $\bar{R}^{2}=0.46$. The evidence thus indicates that outright defendant

18 The estimated equation when all dummies are excluded is $A W A R D=0.195408$ STAKES, with $\bar{R}^{2}=0.3545$ and $t=11.899$ for STAKES $(p<.0001)$ and $F=141.594$ $(p<.0001)$. 
victories are not so contrary to expectations that they significantly increase the unpredictability of litigation.

\section{Judges and Juries}

The United States relies on juries in civil litigation far more than other industrial democracies. Some critics of the U.S. litigation regime argue that the use of juries rather than judges to render decisions on liability and the size of damages is a major source of error. The Organization for Economic Cooperation and Development, for example, asserted in a comparative study of product-liability regimes that "judges tend to adhere more strictly to statutory or common law restrictions and, as a consequence, be less swayed by sympathetic feelings for the injured plaintiff." 19 The fact that in Ireland, the only other such country to place product-liability adjudication in the hands of juries, damages are six times greater on average than what British judges award is said to be evidence for the erratic tendencies of juries. ${ }^{20}$

The CLRP data were limited in that the number of cases in which the manner of adjudication as between judge and jury was known is small. Given the small number of cases of each type, including dummy variables for case types did not allow for sufficiently reliable hypothesis testing. Thus, only the stakes variable is included. As Table 3 indicates, the predictability of outcomes is strongly confirmed for cases decided by judges and juries, even given the modest number of observations. For judges, the correlation coefficient between stakes and court awards is $\rho=0.58$, and the proportion of variance explained is $\bar{R}^{2}=0.40$ for the simple ordinary least squares estimation.

The results for jury trials are almost indistinguishable from those for judge trials, with $\rho=0.50$ and $\bar{R}^{2}=0.35$. Even with the small number of observations, the analysis decisively rejects the hypothesis that jury trials are largely random events, as litigant expectations actually explain more than a third of the variance in awards. In addition, contrary to much of the conventional wisdom, the behavior of judges is not significantly more predictable than that of juries. In fact, although the number of observations shrinks further when zero awards are deleted, so that point estimates of coefficients become more hazardous, without them juries become slightly more predictable than judges. These results are contained in panel B of Table 3.

\footnotetext{
${ }^{19}$ Organization for Economic Cooperation and Development, Product Liability Rules in OECD Countries 26 (1995).

${ }^{20} \mathrm{Id}$. at 27.
} 
TABLE 3

JUDGES AND JURIES

\begin{tabular}{lcc}
\hline \hline & Judges & Juries \\
\hline A. Including outright defendant victories: & & \\
$\rho$ & .57663 & .54171 \\
Regression: STAKES & .240278 & .082648 \\
$t$-statistic & 7.404 & 4.125 \\
$\quad p$ & $<.0001$ & $<.0001$ \\
$\bar{R}^{2}$ & .4022 & .3481 \\
$F$ & 54.819 & 17.020 \\
$p$ & $<.0001$ & $<.0001$ \\
$N$ & 80 & 30 \\
B. Without outright defendant victories: & .58596 & .60895 \\
$\rho$ & .253939 & .107618 \\
Regression: STAKES & 6.179 & 4.521 \\
$t$-statistic & $<.0001$ & $<.0002$ \\
$\quad p$ & .4216 & .4580 \\
$\bar{R}^{2}$ & 38.174 & 20.436 \\
$F$ & $<.0001$ & $<.0002$ \\
$p$ & 51 & 23 \\
\hline
\end{tabular}

The results here provide an interesting companion to those of Kevin Clermont and Theodore Eisenberg, who found significant differences in judge and jury trials, albeit ones that do not agree with public perceptions. By conducting a simple examination of plaintiff demands and court awards in judge and jury trials in federal courts, they found that in product-liability and malpractice cases, plaintiffs win more often in front of judges than juries. ${ }^{21}$ They argued that this belies the common image of juries that lose their senses when sympathetic plaintiffs oppose wealthy or powerful defendants. The findings here are complementary, indicating that jury trials are not more speculative ventures than trials in front of a judge.

In addition, the CLRP data provide additional support for a second empirical result of Clermont and Eisenberg. They speculated that substantial selection effects are at work in determining what sorts of cases are tried in front of judges and juries, which is further evidence that the common assumptions about jury trials outlined above are unwarranted..$^{22}$ They argue that the fact that plaintiff win rates in front of judges and juries are different

${ }^{21}$ Kevin Clermont \& Theodore Eisenberg, Trial by Jury or Judge: Transcending Empiricism, 77 Cornell L. Rev. 1124 (1992). Their hypothesis testing involved primarily comparisons of means rather than more sophisticated attempts to standardize for differences among cases.

${ }^{22}$ Id. 
at a statistically significant level provides evidence that judge and jury trials are governed by different rules. The inference they draw is that judges and juries evaluate evidence and apply the law in consequentially different ways and litigants incorporate these patterns in deciding whether to go to trial. The above data provide a way to test whether judge and jury trials are equivalent processes. The method requires defining the error in attorney stakes estimates, AWARD - STAKES. If the observations for error in jury and judge trials are thought of as separate samples from the pool of all trials, there are two competing hypotheses: that they are two draws from the same underlying distribution or from two separate distributions. The latter hypothesis would indicate that there are substantive differences in the way judges and juries make decisions on damage awards.

The appendix reports the results of testing the null hypotheses that the samples for judge and jury trials come from populations with identical variances and identical means, under the assumption that the errors are normally distributed. The test statistic for the hypothesis of equal variance is distributed $F$ with $\left(n_{1}-1, n_{2}-1\right)$ degrees of freedom, where $n_{1}$ and $n_{2}$ are the sizes of the two samples. The results indicate that the hypothesis that the two populations have the same variance is strongly rejected $(p<.0001)$. There is thus reason to believe that jury trials do yield different ex post error than judge trials.

Assuming unequal variance, the test statistic for whether the two populations have equal means is distributed $t$, using the Satterthwaite degrees-offreedom approximation. ${ }^{23}$ Given unequal variance, the test statistic for the equal means hypothesis is $t=-1.3606$ with approximately 36.5 degrees of freedom. The chance of observing this value with equal means for judge and jury trials is above conventional standards of statistical significance $(p<.1820)$. The inference is that proportionate mistakes in judge trials have different dispersion from those in jury trials, but no inference can be made about the mean of those mistakes. The first result suggests that judge and jury trials are not governed by the same rules. ${ }^{24}$

\section{Trials and the Economic Model of Litigation}

The next task is to examine the extent to which awards reflect the factors that the economic model of litigation indicates they should. It is possible

${ }^{23}$ F. W. Satterthwaite, An Approximate Distribution of Estimates of Variance Components, 2 Biometrics Bull. 110 (1946).

${ }^{24}$ Note that because the folded $F$-statistic is a two-tailed test for the hypothesis of equal variance in two samples, no inferences can be drawn from the test about which type of trial generates greater variance in the residual. The only inference that may be drawn is that the variance in estimation errors by litigants is different in each type of trial. 
that trials are a highly predictable process even as they perform no useful economic function. For example, trial awards may be a function of the skill of the opposing attorneys rather than the evidence and the law. If the trial skills of the own and opposing attorneys are well known, then those factors will be incorporated into the information set litigants use to generate an expected trial outcome. However, there is no reason to suppose that such differential skill levels would reflect economically important issues in the dispute. ${ }^{25}$ Courts might also be known to favor defendants or plaintiffs for economically irrelevant reasons, such as a desire to redistribute wealth to more "deserving" parties. In this section, dollar awards are thus measured against measurable dollar valuations of damages, which in all economic analysis of lawsuits are relevant in determining what the trial outcome should be.

\section{A. The Data}

The CLRP data contain no measure of actual damage. However, another litigation set compiled by the Rand Corporation in 1989 and 1990 does. The data were compiled from state-court tort lawsuits involving nongovernmental litigants in Fairfax County, Virginia. ${ }^{26}$ The set contains estimates by the litigants of medical costs and monetary damages suffered from lost or damaged property. Data are also available on court awards for the cases that proceeded to a verdict. Here I confine the analysis to court cases and ignore cases that were decided by arbitration panels, as it is court behavior that draws most of the public policy criticism. The data are not ideal, in that cases in which claimed damages exceeded $\$ 35,000$ were excluded from the survey. Some of the criticism of the litigation regime's unreliability involves large damages, including punitive damages. However, it is tort litigation, especially products-liability litigation, that is most often assailed by critics. ${ }^{27}$ Since large damages are said to be costly primarily because they are unpredictable rather than because they are large per $\mathrm{se}^{28}{ }^{28}$ the analysis in Section II, in which awards had a much greater range, addressed this objection.

${ }^{25}$ One could argue that the most worthy cases attract the best advocates, but there is no evidence on this proposition. It is also plausible that high-skill attorneys enjoy challenges and are thus drawn to long-shot cases.

${ }^{26}$ Allen A. Lind et al., Survey of Tort Litigants in Three State Courts, 1989-1990: United States (1992).

${ }^{27}$ McGuire, supra note 1.

${ }^{28} \mathrm{Id}$. 


\section{B. Methodology}

Several types of cases were included in the Rand data set. The questionnaire asked respondents to classify the suit as a motor vehicle accident, other accident or injury, property damage or loss, assault (and battery), false arrest or imprisonment, fraud or false representation, or slander, libel, or other defamation. Wrongful-death cases were excluded from the original sample, so there are no confounding effects from the difficulties of calculating the value of human life. The variety of different types of torts means that the measurable proxies for economic loss are different from case to case. For example, in some cases damage to property is the relevant measure of such loss, while in others the replacement value of the property may be more appropriate. In some cases there are medical expenses, in others, damages against assets that are harder to precisely value, such as reputation. Given the modest number of observations, it would not have been possible to conduct testing on each category of damage because the number of cases of each type would have been too small.

Thus, the approach taken is to obtain a total estimate for damages that is the sum of all possible types of damage found in the various types of litigation in the survey. When a particular type of damage (such as medical expenses) is not relevant for the observation in question, that measure takes the value zero. The estimations thus employ the variable DAMAGE, which is defined as

$$
\begin{aligned}
\text { DAMAGE }= & \text { MEDEXPPR }+ \text { MEDEXPFU } \\
& +\max \{\text { PROPDMGE, REPLVAL }\}+\text { OTHER } .
\end{aligned}
$$

The variable $M E D E X P P R$ represents any medical expenses already incurred as the result of the dispute-generating incident, MEDEXPFU is anticipated future medical expenses, PROPDMGE is the cost of repairing property, REPLVAL is the cost to replace destroyed property, and OTHER is any other expenses that plaintiff incurred (excluding costs of the litigation itself) as a consequence of the incident. Almost all observations concerning property damage contained information on either the replacement value of the property or property damage, but not both. For the small number that contained both figures, (1) indicates that the larger value was used. The components of DAMAGE are all taken from plaintiffs' responses to questions about various explicit monetary costs incurred as a result of the incident. The model was tested both with and without subtracting insurance rebates from the total damage calculation, and in each case the best fit was obtained by using gross rather than net damages. Gross damages are thus employed in the results reported here. Finally, while in Section II predict- 
ability was the issue and zero awards were thus of interest, here the issue of interest is the extent to which awarded damages reflect economic damages. Thus, observations with awards of zero were deleted, but observations with any positive awards, even "ceremonial" awards such as $\$ 1$, were included.

\section{Results}

The regression was conducted on DAMAGE and JUDGE, which is a dummy variable taking the value of one if the verdict was rendered by a judge and zero if it was rendered by a jury. The estimated equation is

$$
A W A R D=0.043391 \text { DAMAGE }+5,871.980567 \text { JUDGE } .
$$

The damages proxy is significant at the 0.1 percent level, while JUDGE is not significant $(p<.29)$. One null hypothesis, of all zero coefficients, is conclusively rejected $(F=13.582, p<.001)$. Another null hypothesis, that the manner of adjudication is irrelevant to the economic accuracy of courts, cannot be rejected. Most important, the measurable damages to property and body explain a significant amount of the variance in awards $\left(\bar{R}^{2}=\right.$ $0.21)$. This figure is impressive for a modest cross-sectional sample, given that there were some economically important damages that were not included in the data and that there was no attempt in the survey from which the data were compiled to discriminate between compensatory and punitive damages. Perhaps the most obvious example of economically relevant damages not included in the data is the value of lost work time. Despite this, over 20 percent of the variance in awards is explained simply by measuring variance in medical expenses and property damage.

Because of the small number of observations $(N=46)$, the precision of the point estimates is hardly definitive. However, even with this small sample size, the results indicate that, when awards are made, economic considerations make significant contributions to the size of awards. At the same time, other factors may come into play, as the amount of unexplained variance in this sample, some of which is attributable to unmeasured economic damage, is still high. However, at least at the level of the ordinary, gardenvariety tort lawsuit, the justice system seems to a significant degree to be accomplishing what the economic analysis of law indicates it should.

\section{Concluding Remarks}

This article set out to examine the ability of the U.S. court system to carry out a consistent, economically sound pattern of judgment. The findings cast doubt on several widely held beliefs about the nature of civil liti- 
gation in the United States. Court awards are a highly predictable process, a result that is robust with respect to verdicts rendered by juries and judges. As for the economic utility of this process, the results are somewhat more tentative in terms of precision but nonetheless persuasive as a matter of overall hypothesis testing. Economically relevant costs such as medical expenses and property damage explain a significant proportion of the variance in court awards.

Regardless of the extent to which economically important factors determine court awards, attorneys, who are the firms employed by the litigants who must decide on the disposition of lawsuits, seem to be able to substantially anticipate how courts dispense those awards. To the extent that wildcard juries or attorney skill are important in determining awards, attorneys are evidently aware of how these considerations matter, since the awards themselves are significantly predictable. This reliability may explain the well-known fact that nearly all lawsuits that are filed do not proceed to a verdict.

In addition, evidence was found to support the hypothesis that judge trials and jury trials do operate under different yet understandable rules. The dispersion of the estimation error of litigants and their attorneys was distributed differently for each type of trial. This evidence supports earlier findings that the two types of trials are different, and this article was able to demonstrate that in each case attorneys are in large measure able to ascertain these differences. The exact nature of these differences has not been investigated empirically, which would be an interesting direction for future research.

The findings, while noteworthy, contain some omissions that it would be useful to account for in further research. Most important, the data on economically relevant factors in damage calculation did not contain information on many of these factors, most obviously loss of pay. In addition, because the data deleted some larger awards, the examination of data containing such awards would be an important step in further examination of the economic efficiency of trials.

\section{APPENDIX}

Differences in Error Distribution, Judge and Jury Trials

Judge trials: $\mu=-19,224.537500, \sigma=76,328.96982$.

Jury trials: $\mu=-54,128.866667, \sigma=132,511.69787$.

Equality of error variance: $H_{0}$ (equal variance): $F(29,79)=3.01(p<0.0001)$. Equality of error means: $H_{0}$ (equal means, given unequal variance): $t(36.5)=$ $1.3606(p<0.1820)$. 